\title{
Copper-Dependent Inhibition of Human Cytochrome $c$ Oxidase by a Dimeric Conformer of Amyloid- $\beta_{1-42}$
}

\author{
Peter J. Crouch, ${ }^{1}$ Rachel Blake, ${ }^{1}$ James A. Duce, ${ }^{1}$ Giuseppe D. Ciccotosto, ${ }^{2,3}$ Qiao-Xin Li, ${ }^{2,3}$ Kevin J. Barnham, ${ }^{2,3}$ \\ Cyril C. Curtain, ${ }^{2,3,4}$ Robert A. Cherny, ${ }^{2,3}$ Roberto Cappai, ${ }^{2,3}$ Thomas Dyrks, ${ }^{5}$ Colin L. Masters, ${ }^{1,2,3}$ and Ian A. Trounce ${ }^{1}$ \\ ${ }^{1}$ Centre for Neuroscience and ${ }^{2}$ Department of Pathology, The University of Melbourne, Victoria 3010, Australia, ${ }^{3}$ Mental Health Research Institute of \\ Victoria, Parkville, Victoria 3052, Australia, ${ }^{4}$ School of Physics and Materials Engineering, Monash University, Clayton, Victoria 3168, Australia, and \\ ${ }^{5}$ Diagnostics and Radiopharmacy Research, Schering AG, D-13342 Berlin, Germany
}

In studies of Alzheimer's disease pathogenesis there is an increasing focus on mechanisms of intracellular amyloid- $\beta(\mathrm{A} \beta)$ generation and toxicity. Here we investigated the inhibitory potential of the 42 amino acid $\mathrm{A} \beta$ peptide $\left(\mathrm{A} \beta_{1-42}\right)$ on activity of electron transport chain enzyme complexes in human mitochondria. We found that synthetic $\mathrm{A} \beta_{1-42}$ specifically inhibited the terminal complex cytochrome $c$ oxidase (COX) in a dose-dependent manner that was dependent on the presence of $\mathrm{Cu}^{2+}$ and specific "aging" of the $\mathrm{A} \beta_{1-42}$ solution. Maximal COX inhibition occurred when using $\mathrm{A} \beta_{1-42}$ solutions aged for $3-6 \mathrm{~h}$ at $30^{\circ} \mathrm{C}$. The level of $\mathrm{A} \beta_{1-42}$-mediated $\mathrm{COX}$ inhibition increased with aging time up to $\sim 6 \mathrm{~h}$ and then declined progressively with continued aging to $48 \mathrm{~h}$. Photo-induced cross-linking of unmodified proteins followed by SDS-PAGE analysis revealed dimeric $\mathrm{A} \beta$ as the only $\mathrm{A} \beta$ species to provide significant temporal correlation with the observed COX inhibition. Analysis of brain and liver from an Alzheimer's model mouse (Tg2576) revealed abundant A $\beta$ immunoreactivity within the brain mitochondria fraction. Our data indicate that endogenous $\mathrm{A} \beta$ is associated with brain mitochondria and that $\mathrm{A} \beta_{1-42}$, possibly in its dimeric conformation, is a potent inhibitor of $\mathrm{COX}$, but only when in the presence of $\mathrm{Cu}^{2+}$. We conclude that $\mathrm{Cu}^{2+}$-dependent $\mathrm{A} \beta$-mediated inhibition of $\mathrm{COX}$ may be an important contributor to the neurodegeneration process in Alzheimer's disease.

Key words: Alzheimer’s disease; amyloid- $\beta$; cytochrome oxidase; copper; mitochondria; Tg2576

\section{Introduction}

Alzheimer's disease (AD) is a neurological disorder characterized by the deposition of amyloid- $\beta(\mathrm{A} \beta)$ plaques and progressive loss of cognitive function (Selkoe, 2001). The degree of cognitive impairment occurs relative to soluble $\mathrm{A} \beta$ load (McLean et al., 1999; Naslund et al., 2000), and mutations have been found in familial $\mathrm{AD}$ pedigrees that lead to elevated levels of $\mathrm{A} \beta$ production, particularly the 42 amino acid form $\left(\mathrm{A} \beta_{1-42}\right)$, through altered processing of the $\mathrm{A} \beta$ precursor protein (APP) (Citron et al., 1992; Selkoe, 2001). Early research into the role of $A \beta$ in $A D$ focused on extracellular fibrillar $\mathrm{A} \beta$ as the causative agent for this disease (Pike et al., 1991; Hardy and Higgins, 1992), but there is growing evidence to suggest that the toxic species of $A \beta$ occurs within a soluble, intracellular pool (Hartley et al., 1999; McLean et al., 1999; Dahlgren et al., 2002; Dodart et al., 2002; Walsh et al., 2002; Wang et al., 2002).

Despite the apparent link between $\mathrm{A} \beta$ and the development of $\mathrm{AD}$, and the consistent feature that the $\mathrm{AD}$ brain is under severe oxidative stress (Martins et al., 1986), the underlying biological

Received 0ct. 14, 2004; revised Nov. 19, 2004; accepted Nov. 25, 2004.

This work was supported in part by National Health and Medical Research Council Program Grant 208798. We also thank Prana Biotechnology Ltd. and Schering AG Berlin for support.

Correspondence should be addressed to Dr. lan Trounce, Centre for Neuroscience, The University of Melbourne, Victoria 3010,Australia.E-mail: i.trounce@unimelb.edu.au.

DOI:10.1523/JNEUROSCI.4276-04.2005

Copyright $\odot 2005$ Society for Neuroscience $\quad$ 0270-6474/05/250672-08\$15.00/0 mechanisms responsible for the neurodegeneration characteristic of this disease remain uncertain. One $A \beta$-mediated mechanism for the development of $\mathrm{AD}$ that has gained some support is mitochondrial dysfunction. Analyses of the AD brain provide evidence for decreased abundance and activity of cytochrome $c$ oxidase (COX) (also known as complex IV) from the mitochondrial electron transport chain (ETC) (Maurer et al., 2000; Cottrell et al., 2001, 2002), decreased glucose metabolism (Duara et al., 1986; Haxby et al., 1986), and ultrastructural changes to the mitochondria (Hirai et al., 2001; Casley et al., 2002b). Furthermore, in vitro studies have shown that the disruption of normal mitochondrial functioning can be achieved by exposure to $\mathrm{A} \beta$. Canevari et al. (1999) and Casley et al. (2002a) observed that when supplied to nonsynaptic brain mitochondria from rats, a truncated form of the $\mathrm{A} \beta$ peptide $\left(\mathrm{A} \beta_{25-35}\right)$ specifically inhibits $\mathrm{COX}$, whereas complexes I and II+III of the ETC remain unaffected. Similarly, Parks et al. (2001) reported $\mathrm{A} \beta_{25-35}$-mediated inhibition of COX, but not the other ETC enzyme complexes, in mitochondria isolated from rat liver. These studies suggest that mitochondrial dysfunction may be at least in part a causative factor in the pathology of $\mathrm{AD}$ and that the observed mitochondrial dysfunction may be the result of $\mathrm{A} \beta$-mediated inhibition of $\mathrm{COX}$ activity.

We examined the direct effects of $A \beta_{1-42}$ on activity of the ETC enzyme complexes in mitochondria from cultured human cells. We examined the role of $A \beta_{1-42}$ oligomerization and the 
requirement for $\mathrm{Cu}^{2+}$ in the generation of an $\mathrm{A} \beta$ solution that is able to exert an inhibitory potential toward COX. In addition, we examined mitochondrial fractions from brains and livers of AD transgenic mice (Tg2576) for the presence of APP and A $\beta$. Our aims were to determine whether the presence of a particular $A \beta$ species is required to generate $\mathrm{A} \beta$-mediated inhibition of $\mathrm{COX}$ and to establish whether $A \beta$ accumulation could be detected within Tg2576 mouse brain mitochondria.

\section{Materials and Methods}

Mitochondrial isolation from cultured cells. Leukocytes isolated from whole human blood from healthy donors were transformed with Epstein-Barr virus to yield lymphoblastoid cells (Wallace et al., 1986), which were then maintained in $100 \mathrm{ml}$ cultures at $37^{\circ} \mathrm{C}$ and $5 \%(\mathrm{v} / \mathrm{v}) \mathrm{CO}_{2}$ in RPMI 1640 medium (Invitrogen, San Diego, CA) supplemented with $10 \%(\mathrm{v} / \mathrm{v})$ fetal bovine serum (Invitrogen). Cells were seeded into $2 \mathrm{~L}$ roller bottles in $250 \mathrm{ml}$, passaged to $1 \mathrm{~L}$ after 3 or $4 \mathrm{~d}$ growth, and then harvested for the isolation of mitochondria once the cells reached a density of $1.0-1.5 \times 10^{6}$ cells $\mathrm{ml}^{-1}$ in late $\log$ growth phase. Intact mitochondria were isolated from lymphoblast cells as described previously (Trounce et al., 1996), except that the final mitochondrial pellet was suspended in EGTA-free isolation buffer.

Mitochondrial isolation from mouse brain and liver. Tg2576 (Hsiao et al., 1996) and wild-type (WT) mice were housed, bred, and genotyped as described previously (Maynard et al., 2002). Mice were killed at 18 months of age by cervical dislocation and then dissected to remove the brains and livers. Total brain mitochondria isolates were prepared from fresh brains using Percoll gradients as described by Anderson and Sims (2000). Fresh liver samples (on ice) were minced to a paste with scissors, diluted to $10 \%(\mathrm{w} / \mathrm{v})$ with ice-cold isolation buffer (as per cell culture mitochondria isolation buffer), and then homogenized in a Dounce homogenizer (12 strokes loose pestle, 4 strokes tight pestle). The homogenate was centrifuged four times at $600 \times g\left(10 \mathrm{~min}\right.$ per spin at $\left.4^{\circ} \mathrm{C}\right)$ and then once at $5000 \times g\left(10 \mathrm{~min}, 4^{\circ} \mathrm{C}\right)$; the supernatant fraction was centrifuged each time. Pelleted material from the final spin was resuspended with $20 \mathrm{ml}$ fresh isolation buffer and centrifuged at $5000 \times g$. The resulting crude mitochondria pellet was purified further by resuspending in isolation buffer containing 14\% (v/v) Percoll and fractionating through a Percoll density gradient as described by Anderson and Sims (2000). Aliquots of the initial brain and liver homogenates were stored at $-80^{\circ} \mathrm{C}$ and used for SDS-PAGE and Western blot analysis alongside mitochondrial fractions.

Protein content and storage of mitochondria isolates. Total protein in the mitochondria isolates was determined using a modified version of Lowry et al. (1951) as described by Peterson (1977). Mitochondrial protein was determined as the difference between total protein content of the isolates and the BSA content of the isolation buffer. Mitochondrial membranes were disrupted by subjecting the isolates to a $3 \times$ freeze-thaw cycle at $-80^{\circ} \mathrm{C}$, and the isolates were stored in aliquots at $-80^{\circ} \mathrm{C}$.

$A \beta$ solution preparation. Synthetic $\mathrm{A} \beta_{1-42}$ or $\mathrm{A} \beta_{42-1}$ (W. M. Keck Foundation Biotechnology Resource Laboratory, Yale University, New Haven, CT) was dissolved in $20 \mathrm{~mm} \mathrm{NaOH}$ and then diluted with $10 \times$ PBS (1.45 M NaCl, $75 \mathrm{~mm} \mathrm{Na}_{2} \mathrm{HPO}_{4}, 2.4 \mathrm{~mm} \mathrm{NaH}_{2} \mathrm{PO}_{4}, \mathrm{pH}$ 7.2) and MilliQ water to yield a $200 \mu \mathrm{M} \mathrm{A} \beta$ solution with a final $\mathrm{pH}$ of 8.0 and $1 \times$ PBS concentration. When required, $\mathrm{Cu}^{2+}$ (as a $7 \mathrm{mM} \mathrm{CuCl}_{2}, 42 \mathrm{mM}$ glycine stock) was added to $400 \mu \mathrm{M}$ to provide a final $\mathrm{A} \beta / \mathrm{Cu}^{2+}$ molar ratio of $1: 2 . \mathrm{Zn}^{2+}, \mathrm{Fe}^{2+}$, or $\mathrm{Fe}^{3+}$ was added by substituting $\mathrm{CuCl}_{2}$ with $\mathrm{ZnCl}_{2}, \mathrm{FeSO}_{4}$, or $\mathrm{FeCl}_{3}$. $\mathrm{A} \beta$ and vehicle solutions are referred to with respect to their metal cation form only $\left(\mathrm{A} \beta_{1-42} / \mathrm{Cu}^{2+}\right.$, vehicle/ $\mathrm{Fe}^{3+}$, $\mathrm{A} \beta_{42-1} / \mathrm{Zn}^{2+}$ etc). Vehicle solutions used as negative controls were identical to the appropriate $\mathrm{A} \beta$ solutions but contained no $\mathrm{A} \beta$. $\mathrm{A} \beta$ and vehicle solutions were incubated at $30^{\circ} \mathrm{C}$ for the times specified before their incubation with mitochondrial isolates.

$A \beta /$ mitochondria incubations. Cell-culture mitochondria isolates (10 $\mu \mathrm{l})$ were incubated with $50 \mu \mathrm{l} \mathrm{A} \beta$ or vehicle solution for $5 \mathrm{~min}$ at $30^{\circ} \mathrm{C}$ and then kept on ice until assayed for enzyme activities. The period on ice before assaying never exceeded $3 \mathrm{~min}$. Using these volumes and an initial
$200 \mu \mathrm{M} A \beta$ solution, the final $\mathrm{A} \beta$ concentration in the incubation mixture was $167 \mu \mathrm{M}$.

Enzymology. The mitochondrial ETC enzyme complexes I, II, III, and IV (COX) and the mitochondrial matrix enzyme citrate synthase were assayed as described by Trounce et al. (1996). Briefly, complex I was measured as the rate of decylubiquinone-dependent, rotenone-sensitive oxidation of $\beta$-nicotinamide adenine dinucleotide by monitoring $\Delta \mathrm{Abs}$ at $340 \mathrm{~nm}$; complex II as the rate of decylubiquinone-dependent oxidation of succinate by monitoring the coupled reduction of 2,6dichloroindolphenol at $600 \mathrm{~nm}$; complex III as the rate of decylubiquinol-dependent, antimycin A-sensitive reduction of cytochrome $c$ at $550 \mathrm{~nm}$; COX as the rate of cyanide-sensitive cytochrome $c$ oxidation at $550 \mathrm{~nm}$; and citrate synthase as the rate of oxaloacetatedependent reduction of acetyl-CoA by monitoring the coupled reduction of 5,5'-dithio-bis(2-nitrobenzoic acid) at $412 \mathrm{~nm}$.

Photo-induced cross-linking of unmodified proteins, SDS-PAGE, and Western blotting for synthetic $A \beta$. Synthetic $A \beta$ species in solution (dimers, trimers, etc.) were cross-linked using photo-induced crosslinking of unmodified proteins (PICUP) (Fancy and Kodadek, 1999), as modified for its application to $A \beta$ preparations by Bitan et al. (2001, $2003 \mathrm{a}, \mathrm{b})$. While kept in the dark, $12 \mu \mathrm{l}$ of $\mathrm{A} \beta$ preparation $(200 \mu \mathrm{m}$ total $\mathrm{A} \beta$ in monomer equivalents) was added to $6 \mu \mathrm{l}$ of $1 \mathrm{~mm} \operatorname{Tris}\left(2,2^{\prime}\right.$ bipyridyl)dichlororuthenium(II) and $6 \mu 120 \mathrm{~mm}$ ammonium persulfate in $10 \mathrm{mM} \mathrm{Na}_{2} \mathrm{HPO}_{4}, \mathrm{pH}$ 7.4. Cross-linking was initiated by exposing the mixture to a $200 \mathrm{~W}$ incandescent light for exactly $0.5 \mathrm{~s}$ and then terminated by adding $24 \mu \mathrm{l}$ of gel loading buffer [ $100 \mathrm{~mm}$ Tris, $10 \%(\mathrm{v} / \mathrm{v})$ glycerol, $4 \%(\mathrm{v} / \mathrm{v})$ SDS, $4 \%(\mathrm{v} / \mathrm{v}) \beta$-mercaptoethanol, $0.01 \%$ (w/v) bromophenol blue]. Exposure time was controlled by passing the light through the body of a single-lens reflex camera and setting the shutter speed to $0.5 \mathrm{~s}$. Cross-linked $\mathrm{A} \beta$ preparations in loading buffer were kept at $-80^{\circ} \mathrm{C}$ until required for SDS-PAGE analyses. A $\beta$ species were separated on 1-mm-thick 15\% Tris-tricine gels, transferred to nitrocellulose membranes, probed with the monoclonal mouse antibody WO2 for human A $\beta$ (Ida et al., 1996), and then reprobed with horseradish peroxidase-linked anti-mouse IgG. A $\beta$ bands were visualized by enhanced chemiluminescence (ECL Western Blotting Detection Reagents, Amersham Biosciences, Arlington Heights, IL), and the relative abundance of each $\mathrm{A} \beta$ species was determined by densitometry (Scion Image, Frederick, MD).

SDS-PAGE and Western blotting for APP and A $\beta$ in mouse tissues. Proteins $(50 \mu \mathrm{g})$ in mouse brain and liver samples were diluted with loading buffer [100 mm Tris, 10\% (v/v) glycerol, 4\% (v/v) SDS, 4\% (v/v) $\beta$-mercaptoethanol, $0.01 \%$ (w/v) bromophenol blue], separated on $10-$ $20 \%$ Tris-tricine gels (Gradipore, Frenchs Forrest, New South Wales, Australia), and then Western blotted and visualized as described for synthetic $A \beta$. Purity of the mitochondria samples was determined by reprobing the membrane with $\mathrm{HO}-1$ for endoplasmic reticulum (Stressgen, Victoria, British Columbia, Canada) and then stripping and probing with Porin (Molecular Probes, Eugene, OR) for mitochondria.

\section{Results}

\section{Soluble $\mathrm{A} \boldsymbol{\beta}_{1-42} / \mathrm{Cu}^{2+}$ inhibits COX}

We examined whether aging freshly prepared $\mathrm{A} \beta_{1-42} / \mathrm{Cu}^{2+}$ at $30^{\circ} \mathrm{C}$ would lead to the formation of an $\mathrm{A} \beta_{1-42} / \mathrm{Cu}^{2+}$ solution with an inhibitory potential toward COX activity. When incubated with mitochondria isolates for 5 min without previous aging, the $\mathrm{A} \beta_{1-42} / \mathrm{Cu}^{2+}$ solution inhibited COX activity by $28 \%$ relative to the vehicle/ $\mathrm{Cu}^{2+}$ control (Fig. $\left.1 A\right)(p<0.001$; ANOVA; $n=4 \mathrm{~A} \beta$ /vehicle solutions). With aging for up to $6 \mathrm{~h}$, the $\mathrm{A} \beta_{1-42} / \mathrm{Cu}^{2+}$-mediated inhibition of COX increased with increasing aging time to $73 \%$. The correlation between aging of the $\mathrm{A} \beta_{1-42} / \mathrm{Cu}^{2+}$ solution up to $6 \mathrm{~h}$ and inhibition of COX activity was linear $\left(R^{2}=0.96 ; p<0.01\right.$; linear regression analysis). With continued aging after $6 \mathrm{~h}$, the inhibitory effect of the $A \beta_{1-42} /$ $\mathrm{Cu}^{2+}$ solution began to decrease; by $24 \mathrm{~h}$ the inhibitory effect had dropped back to $17 \%$, and by $48 \mathrm{~h}$ it was back to $13 \%$.

Free $\mathrm{Cu}^{2+}$ ions can be lost from solutions with neutral $\mathrm{pH}$ 

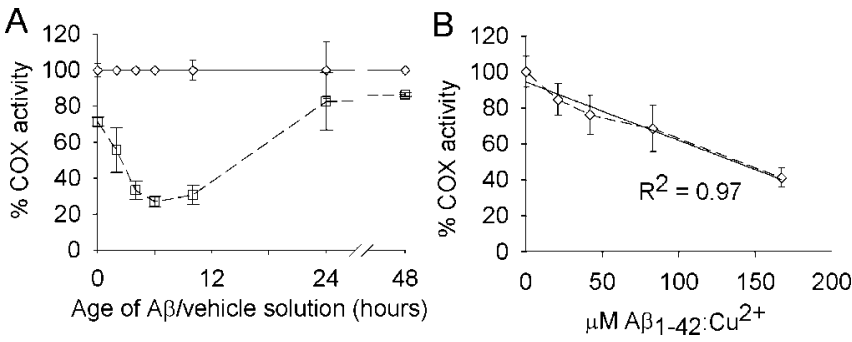

Figure 1. Inhibition of $\mathrm{COX}$ activity by $\mathrm{A} \beta_{1-42}$ solutions aged in the presence of $\mathrm{Cu}^{2+} . A_{\text {, }}$ $\mathrm{A} \beta_{1-42} / \mathrm{Cu}^{2+}(\square)$ and vehicle/ $\mathrm{Cu}{ }^{2+}(\diamond)$ solutions were aged at $30^{\circ} \mathrm{C}$ for the times shown and then incubated with mitochondria isolates for $5 \mathrm{~min}$ before assaying for COX activity. All activities are expressed relative to the vehicle/ $/ \mathrm{Cu}^{2+}$ control. Error margins represent the SD of the mean $(n=4)$. COX activity for vehicle/ $\mathrm{Cu}^{2+}$-treated mitochondria isolates was 9.38 $( \pm 1.12) \mathrm{k} \cdot \mathrm{min}^{-1} \cdot \mathrm{mg}^{-1}$ mitochondrial protein. $B$, Mitochondria isolates were incubated with $A \beta_{1-42} / \mathrm{Cu}^{2+}$ (aged for $5 \mathrm{~h}$ at $30^{\circ} \mathrm{C}$ ) at the concentrations shown and then assayed for $\mathrm{COX}$ activity. All activities are expressed relative to the $0 \mu \mathrm{m} A \beta$ control. Error margins represent the $\mathrm{SD}$ of the mean $(n=4)$. COX activity for $0 \mu \mathrm{mA} \beta$-treated mitochondria isolates was 7.23 $( \pm 0.63) \mathrm{k} \cdot \mathrm{min}^{-1} \cdot \mathrm{mg}^{-1}$ mitochondrial protein.

because of the time-dependent formation of metal-hydroxy and metal-oxy polymers (Huang et al., 1999). Thus, if free $\mathrm{Cu}^{2+}$ is required for the observed $\mathrm{A} \beta_{1-42}$-mediated inhibition of COX activity, it is possible that the observed decrease in COX inhibition with continued aging of the $\mathrm{A} \beta_{1-42} / \mathrm{Cu}^{2+}$ solution beyond $6 \mathrm{~h}$ was caused by the loss of free $\mathrm{Cu}^{2+}$ from solution. To investigate this possibility, $\mathrm{A} \beta_{1-42} / \mathrm{Cu}^{2+}$ solutions were prepared and aged for $48 \mathrm{~h}$ at $30^{\circ} \mathrm{C}$ and then assayed for their effect on COX activity. Consistent with the data shown in Figure $1 \mathrm{~A}$, the 48 -hold $\mathrm{A} \beta_{1-42} / \mathrm{Cu}^{2+}$ inhibited COX activity by only $27 \%$ (data not shown; $p<0.001$; ANOVA; $n=4 \mathrm{~A} \beta /$ vehicle solutions). The addition of fresh $\mathrm{Cu}^{2+}$ (as $400 \mu \mathrm{M} \mathrm{CuCl}_{2}$ ) did not alter the inhibitory effect of the 48 -h-old $\mathrm{A} \beta_{1-42} / \mathrm{Cu}^{2+}$ solution (data not shown; $p=0.11$; ANOVA; $n=4 \mathrm{~A} \beta$ solutions).

The substrate of COX activity is ferrocytochrome $c$ (reduced form of cytochrome $c$ ), and the product is ferricytochrome $c$ (oxidized form). To determine whether $\mathrm{A} \beta_{1-42} / \mathrm{Cu}^{2+}$ itself has any effect on the redox state of cytochrome $c$, the reduced and oxidized forms of cytochrome $c$ were incubated at $30^{\circ} \mathrm{C}$ for $5 \mathrm{~min}$ with $\mathrm{A} \beta_{1-42} / \mathrm{Cu}^{2+}$ or vehicle/ $\mathrm{Cu}^{2+}$ (both of which had been aged for $5 \mathrm{~h}$ ), and then their wavelength spectra were determined. In the presence of vehicle/ $\mathrm{Cu}^{2+}$, ferrocytochrome $c$ exhibited its typical double-peaked spectrum with absorption maxima at 520 and $550 \mathrm{~nm}$, whereas ferricytochrome $c$ exhibited its broader spectrum with a single absorption maximum at $529 \mathrm{~nm}$. Incubation with $\mathrm{A} \beta_{1-42} / \mathrm{Cu}^{2+}$ had no effect on these wavelength spectra (data not shown).

To examine whether the inhibitory effect of the $\mathrm{A} \beta_{1-42} / \mathrm{Cu}^{2+}$ solution could be attributed to soluble or insoluble forms of the $\mathrm{A} \beta$, an $\mathrm{A} \beta_{1-42} / \mathrm{Cu}^{2+}$ solution was prepared and then assayed for its effects on COX activity as per other experiments (i.e., the $\mathrm{A} \beta_{1-42}$ solution was aged for $4 \mathrm{~h}$ at $30^{\circ} \mathrm{C}$ in the presence of $\mathrm{Cu}^{2+}$ and then incubated with mitochondrial isolates for $5 \mathrm{~min}$ at $30^{\circ} \mathrm{C}$ before assaying for COX activity). Under these conditions the $\mathrm{A} \beta_{1-42} / \mathrm{Cu}^{2+}$ solution ("total $\mathrm{A} \beta_{1-42} / \mathrm{Cu}^{2+}$ ") inhibited COX activity by $54 \%$ (data not shown; $p<0.001$; ANOVA; $n=3 \mathrm{~A} \beta /$ vehicle solutions). Aliquots of the same $\mathrm{A} \beta_{1-42} / \mathrm{Cu}^{2+}$ solution were then centrifuged at $15,000 \times g$ for $5 \mathrm{~min}$, and either the supernatant ("soluble $\mathrm{A} \beta_{1-42} / \mathrm{Cu}^{2+}$ ") was assayed directly for its effects on COX activity or the insoluble pelleted material ("insoluble $\mathrm{A} \beta_{1-42} / \mathrm{Cu}^{2+")}$ was resuspended with vehicle/ $\mathrm{Cu}^{2+}$ and then assayed for its effects on COX. All of the inhib-
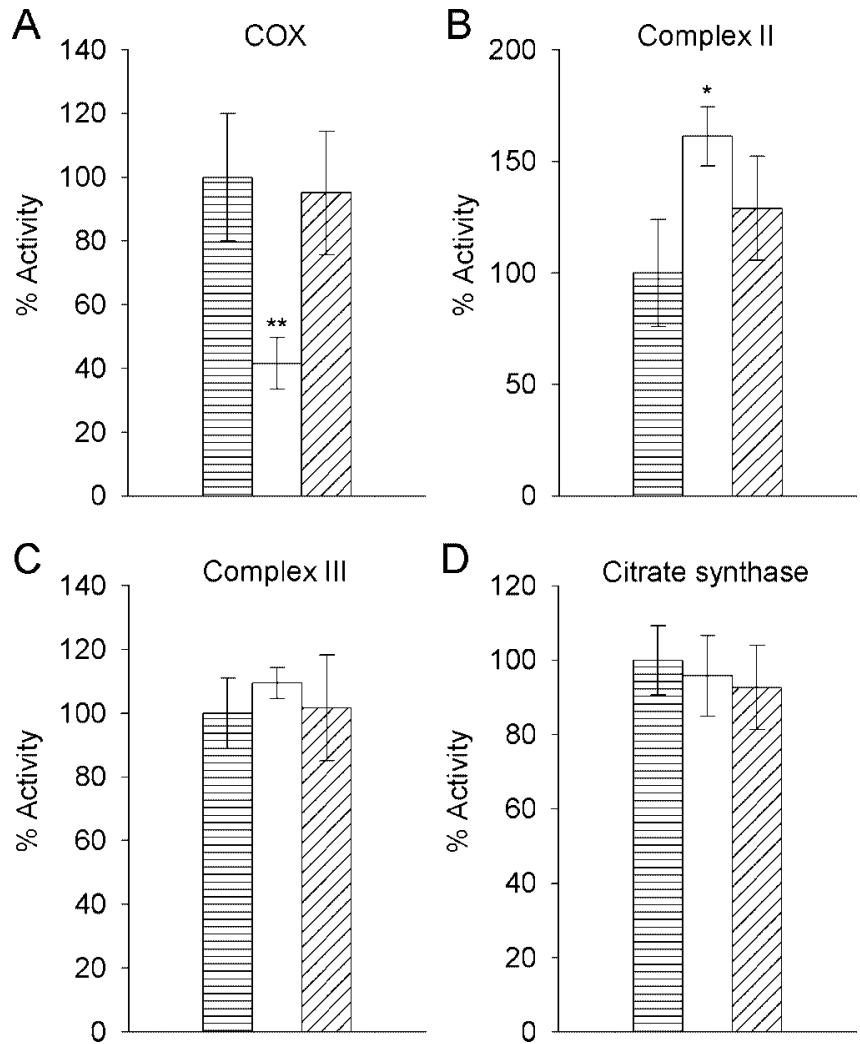

Figure 2. Effects of $A \beta_{1-42} / \mathrm{Cu}^{2+}$ and $A \beta_{42-1} / \mathrm{Cu}^{2+}$ on activity of the electron transport chain enzyme complexes II, III, and $C O X$, and the mitochondrial matrix enzyme citrate synthase. Mitochondria isolates were incubated for 5 min with vehicle/ $\mathrm{Cu}^{2+}\left(\right.$ 呈), $\mathrm{A} \beta_{1-42} / \mathrm{Cu}^{2+}(\square)$, or $\mathrm{A} \beta_{42-1} / \mathrm{Cu}^{2+}(\mathbb{Z})$ solutions that had been aged for $5 \mathrm{~h}$ at $30^{\circ} \mathrm{C}$ and then assayed for the activity of COX $(A)$, complex II (B), complex III ( $C$, and citrate synthase $(D)$. All activities are expressed relative to the vehicle $/ \mathrm{Cu}^{2+}$ control. Error margins represent the SD of the mean $(n=3-5)$. COX activity in vehicle/ $/ \mathrm{Cu}^{2+}$-treated mitochondria was $7.41( \pm 1.48) \mathrm{k} \cdot \mathrm{min}^{-1} \cdot \mathrm{mg}^{-1} \mathrm{mi}$ tochondrial protein. Specific activities ( $\mathrm{min}^{-1} \mathrm{mg}^{-1}$ mitochondrial protein) in vehicle/ $/ \mathrm{Cu}^{2+}$ treated mitochondria for complex II, complex III, and citrate synthase were $26.1( \pm 6.3) \mathrm{nmol}$ succinate, $129.5( \pm 14.3) \mathrm{nmol}$ cytochrome $c$, and $231.6( \pm 21.6) \mathrm{nmol}$ acetyl-CoA, respectively. ANOVA; ${ }^{*} p<0.05$ and ${ }^{* *} p<0.001$ compared with vehicle/ $\mathrm{Cu}^{2+}$ control; $n=3-5$.

itory effect present in the total $\mathrm{A} \beta_{1-42} / \mathrm{Cu}^{2+}$ solution was recovered in the soluble fraction (53\% inhibition of COX; $p<$ 0.001 ; ANOVA; $n=3 \mathrm{~A} \beta$ /vehicle solutions), whereas the insoluble fraction had no effect on COX activity $(p=0.11)$. It remains to be established whether the present $A \beta$ aging and centrifugation conditions were sufficient for the production and/or precipitation of insoluble $\mathrm{A} \beta$.

To determine the dose-dependent affect of $\mathrm{A} \beta_{1-42} / \mathrm{Cu}^{2+}$ on COX activity, a $200 \mu \mathrm{M} \mathrm{A} \beta_{1-42} / \mathrm{Cu}^{2+}$ solution was prepared and aged at $30^{\circ} \mathrm{C}$ for $5 \mathrm{~h}$. Before conducting the $5 \mathrm{~min} \mathrm{~A} \beta /$ mitochondria incubations at $30^{\circ} \mathrm{C}$, the $\mathrm{A} \beta_{1-42} / \mathrm{Cu}^{2+}$ solution was diluted with vehicle solution (without $\mathrm{Cu}^{2+}$ ) to give final $\mathrm{A} \beta$ concentrations of $0,25,50,100$, and $200 \mu \mathrm{M}$ while maintaining the $\mathrm{A} \beta /$ $\mathrm{Cu}^{2+}$ molar ratio of $1: 2$. Using these $\mathrm{A} \beta_{1-42} / \mathrm{Cu}^{2+}$ solutions, the final concentrations of $A \beta$ in the $A \beta /$ mitochondria incubation mixture were $0,21,42,83$, and $167 \mu \mathrm{M}$. Inhibition of COX activity occurred proportional to $\mathrm{A} \beta_{1-42} / \mathrm{Cu}^{2+}$ concentration, with inhibition at $59 \%$ when the mitochondria were incubated with $167 \mu \mathrm{M} \mathrm{A} \beta_{1-42} / \mathrm{Cu}^{2+}$ (Fig. $\left.1 B\right)\left(R^{2}=0.97 ; p<0.01\right.$; linear regression analysis).

Inhibition by $\mathrm{A} \boldsymbol{\beta}_{1-42} / \mathrm{Cu}^{2+}$ is specific to $\mathrm{COX}$

An $\mathrm{A} \beta_{1-42} / \mathrm{Cu}^{2+}$ solution aged for $5 \mathrm{~h}$ at $30^{\circ} \mathrm{C}$ inhibited COX activity by $58 \%$ relative to the vehicle/ $/ \mathrm{Cu}^{2+}$ control (Fig. $2 \mathrm{~A}$ ) 

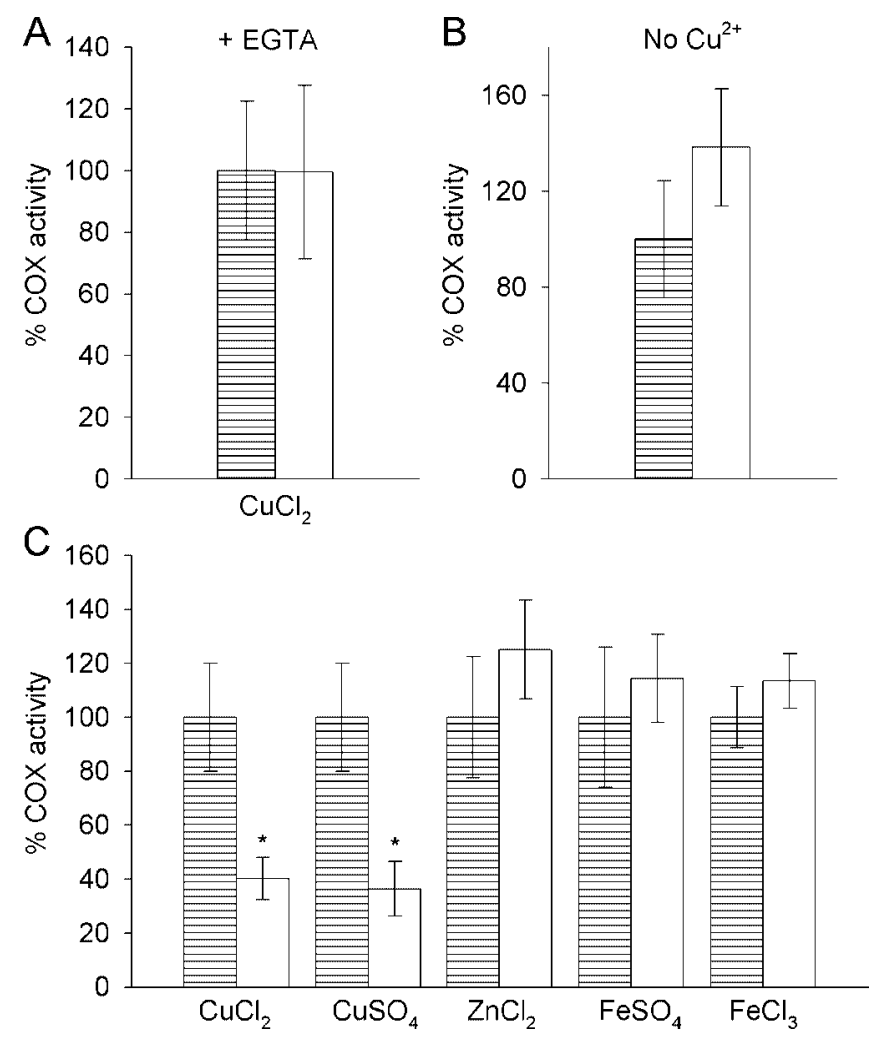

Figure 3. The requirement for $\mathrm{Cu}^{2+}$ in $\mathrm{A} \beta_{1-42}$-mediated inhibition of $\mathrm{COX}$ activity. Mitochondria isolates were incubated for 5 min with vehicle/ $/ \mathrm{Cu}^{2+}$ (冒) or $\mathrm{A} \beta_{1-42} / \mathrm{Cu}^{2+}(\square)$ solutions that had been aged for $5 \mathrm{~h}$ at $30^{\circ} \mathrm{C}$, and subsequent $\mathrm{COX}$ activity in the mitochondria isolates was determined. $A$, EGTA was included in the 5 min incubation at a final concentration of $700 \mu \mathrm{m}$, thus providing an $\mathrm{EGTA} / \mathrm{Cu}^{2+}$ molar ratio of $2: 1 . \mathrm{B}_{1} \mathrm{Cu}^{2+}$ was omitted from the $A \beta_{1-42}$ and vehicle solutions. $C, A \beta_{1-42}$ and vehicle solutions were prepared and aged with $\mathrm{Cu}^{2+}$ (supplied as $\mathrm{CuCl}_{2}$ or $\left.\mathrm{CuSO}_{4}\right), \mathrm{Zn}^{2+}\left(\mathrm{as}_{\mathrm{ZnCl}}\right), \mathrm{Fe}^{2+}\left(\mathrm{as} \mathrm{FeSO}_{4}\right)$, or Fe ${ }^{3+}\left(\mathrm{as} \mathrm{FeCl}_{3}\right)$. All activities are expressed relative to the vehicle controls. Error margins represent the SD of the mean $(n=3-5)$. ANOVA; ${ }^{*} p<0.001$ compared with vehicle controls; $n=3-5$.

( $p<0.001 ;$ ANOVA; $n=5$ mitochondria isolates); however, the same $\mathrm{A} \beta_{1-42} / \mathrm{Cu}^{2+}$ solution had no inhibitory effect on complex II, complex III, or citrate synthase activity (Fig. $2 B-D$ ). In the presence of $A \beta_{1-42} / \mathrm{Cu}^{2+}$, complex II activity increased $61 \%$ (Fig. 2B) $(p<0.05$; ANOVA; $n=3$ mitochondria isolates). This could be significant to $\mathrm{AD}$ pathology if there was an associated increase in the production of free radicals, but it may have been caused by a nonspecific peptide effect because there was no significant difference in complex II activity for $\mathrm{A} \beta_{1-42} / \mathrm{Cu}^{2+}$ - and $\mathrm{A} \beta_{42-1} / \mathrm{Cu}^{2+}$-treated mitochondria ( $p=0.71$; ANOVA; $n=3$ mitochondria isolates). Relative to the vehicle/ $\mathrm{Cu}^{2+}$ control, the reverse peptide $\mathrm{A} \beta_{42-1} / \mathrm{Cu}^{2+}$ had no effect on any of the enzymes studied. Data for the effects of $\mathrm{A} \beta_{1-42} / \mathrm{Cu}^{2+}$ on complex I activity could not be obtained because activity for this enzyme was nondetectable when EGTA was omitted from the mitochondria isolates, even when assayed without treating with $\mathrm{A} \beta_{1-42} / \mathrm{Cu}^{2+}$ or vehicle/ $\mathrm{Cu}^{2+}$. When EGTA was included in the mitochondria isolates, complex I activity could be detected at 23 $\mathrm{nmol} \cdot \min ^{-1} \cdot \mathrm{mg}^{-1}$ protein (data not shown).

\section{$\mathrm{Cu}^{2+}$ is required for $\mathrm{A} \boldsymbol{\beta}_{1-42}$ inhibition of $\mathrm{COX}$}

When $700 \mu \mathrm{M}$ EGTA was included in the $\mathrm{A} \beta /$ mitochondria $5 \mathrm{~min}$ incubation before assaying for COX activity, or when $\mathrm{Cu}^{2+}$ was omitted from the $\mathrm{A} \beta_{1-42}$ preparation, no $\mathrm{A} \beta_{1-42}$-mediated inhibition of COX could be detected (Fig. $3 A, B)(p=0.98$ and 0.07 , respectively; ANOVA; $n=4$ mitochondria isolates). Furthermore, no $\mathrm{A} \beta_{1-42}$-mediated inhibition of COX could be detected when $\mathrm{Cu}^{2+}$ was substituted with $\mathrm{Zn}^{2+}, \mathrm{Fe}^{2+}$, or $\mathrm{Fe}^{3+}$ (Fig. $3 C$ ) $\left(p=0.13,0.32\right.$, and 0.17 for $\mathrm{Zn}^{2+}, \mathrm{Fe}^{2+}$, and $\mathrm{Fe}^{3+}$, respectively; ANOVA; $n=3-5$ mitochondria isolates). The counter ion form of the $\mathrm{Cu}^{2+}$ that was supplied, however, had no effect on the inhibitory potential of the $\mathrm{A} \beta_{1-42} / \mathrm{Cu}^{2+}$. When using $\mathrm{CuCl}_{2}$, the $\mathrm{A} \beta_{1-42} / \mathrm{Cu}^{2+}$ inhibited COX activity by $60 \%$ (Fig. $\left.3 C\right)(p<0.01$; ANOVA; $n=4$ mitochondria isolates), whereas using $\mathrm{CuSO}_{4}$ caused 63\% inhibition (Fig. $3 C)(p<0.001$; ANOVA; $n=5$ mitochondria isolates).

\section{PICUP analysis of $A \boldsymbol{\beta}_{1-42}$ species}

$\mathrm{A} \beta_{1-42} / \mathrm{Cu}^{2+}$ was prepared and aged at $30^{\circ} \mathrm{C}$ as for the other experiments except that after $0,2,4,6,10$, and $24 \mathrm{~h}$ aging, aliquots of the $\mathrm{A} \beta$ solution were collected and either assayed immediately for its effects on COX activity or cross-linked via PICUP for SDS-PAGE analysis. SDS-PAGE analysis revealed the presence of $\mathrm{A} \beta_{1-42}$ species that correlated by molecular weight to monomers, dimers through to hexamers [low molecular weight (LMW) oligomers], and high molecular weight (HMW) $(>45 \mathrm{kDa}) \mathrm{A} \beta$ (Fig. $4 A$ ). At each time point in the $\mathrm{A} \beta$ aging process, the abundance of individual $A \beta$ species was calculated relative to the other $A \beta$ species present at that time. The abundance of monomeric $\mathrm{A} \beta$ remained relatively constant throughout the $24 \mathrm{~h}$ aging period, accounting for $\sim 40 \%$ of total $\mathrm{A} \beta$ at all times. In contrast, the HMW $\mathrm{A} \beta$, presumably consisting of at least some protofibrillar and fibrillar $A \beta$, increased in abundance with increasing aging time (from $\sim 15 \%$ of total $\mathrm{A} \beta$ after $0 \mathrm{~h}$ aging to $\sim 50 \%$ after $24 \mathrm{~h}$ ). Throughout the $24 \mathrm{~h}$ aging period, the LMW A $\beta$ oligomers collectively accounted for only $\sim 20 \%$ of the total $A \beta$. Of these, dimeric $\mathrm{A} \beta$ was the most abundant, accounting for $\sim 10 \%$ of total $\mathrm{A} \beta$.

Given the distinct pattern of COX inhibition observed when mitochondria isolates were incubated with $\mathrm{A} \beta_{1-42} / \mathrm{Cu}^{2+}$ solutions aged for $0-24 \mathrm{~h}$ (Fig. $1 A$ ), we examined whether the abundance of any particular species of $A \beta$ over the $24 \mathrm{~h}$ aging period correlated with COX inhibition. To do this, we plotted $\mathrm{A} \beta_{1-42} /$ $\mathrm{Cu}^{2+}$-mediated COX inhibition (as percentage activity relative to $\mathrm{COX}$ activity in vehicle/ $\mathrm{Cu}^{2+}$-treated mitochondria isolates) against the relative abundance of each $\mathrm{A} \beta$ species present within the $\mathrm{A} \beta_{1-42} / \mathrm{Cu}^{2+}$ solution at any given time in the aging period. We found that of all the $\mathrm{A} \beta$ species detected, only dimeric $\mathrm{A} \beta$ exhibited a significant correlation with COX inhibition (Fig. $4 B$ ) $\left(R^{2}=0.28 ; p<0.01\right.$; linear regression analysis $)$.

\section{APP and A $\beta$ in 18-month-old Tg2576 mouse brain mitochondria}

When 18-month-old Tg2576 mouse brain homogenate was electrophoresed on 10-20\% Tris-tricine gradient gels (50 $\mu \mathrm{g}$ of total protein per lane), Western blot analysis revealed the presence of WO2-immunoreactive bands at $\sim 5$ and $\sim 110 \mathrm{kDa}$, presumably representing $\mathrm{A} \beta$ and APP (Fig. $5 A$ ). The $\sim 5 \mathrm{kDa}$ band comigrated with monomeric $\mathrm{A} \beta$ from a sample of cross-linked synthetic $\mathrm{A} \beta_{1-42}$ equivalent to that shown in Figure $4 A$ (data not shown). The same WO2-immunoreactive bands were detected in the Tg2576 mouse brain mitochondrial fraction, with the APP being considerably less abundant, whereas the $\mathrm{A} \beta$ was greatly enriched. No WO2 immunoreactivity was observed in either fraction of the WT mouse brain. Purity of the brain mitochondria fraction was established by Western blotting total brain homogenate and brain mitochondria samples with Porin (for mitochondria) and HO-1 (for endoplasmic reticulum, a 


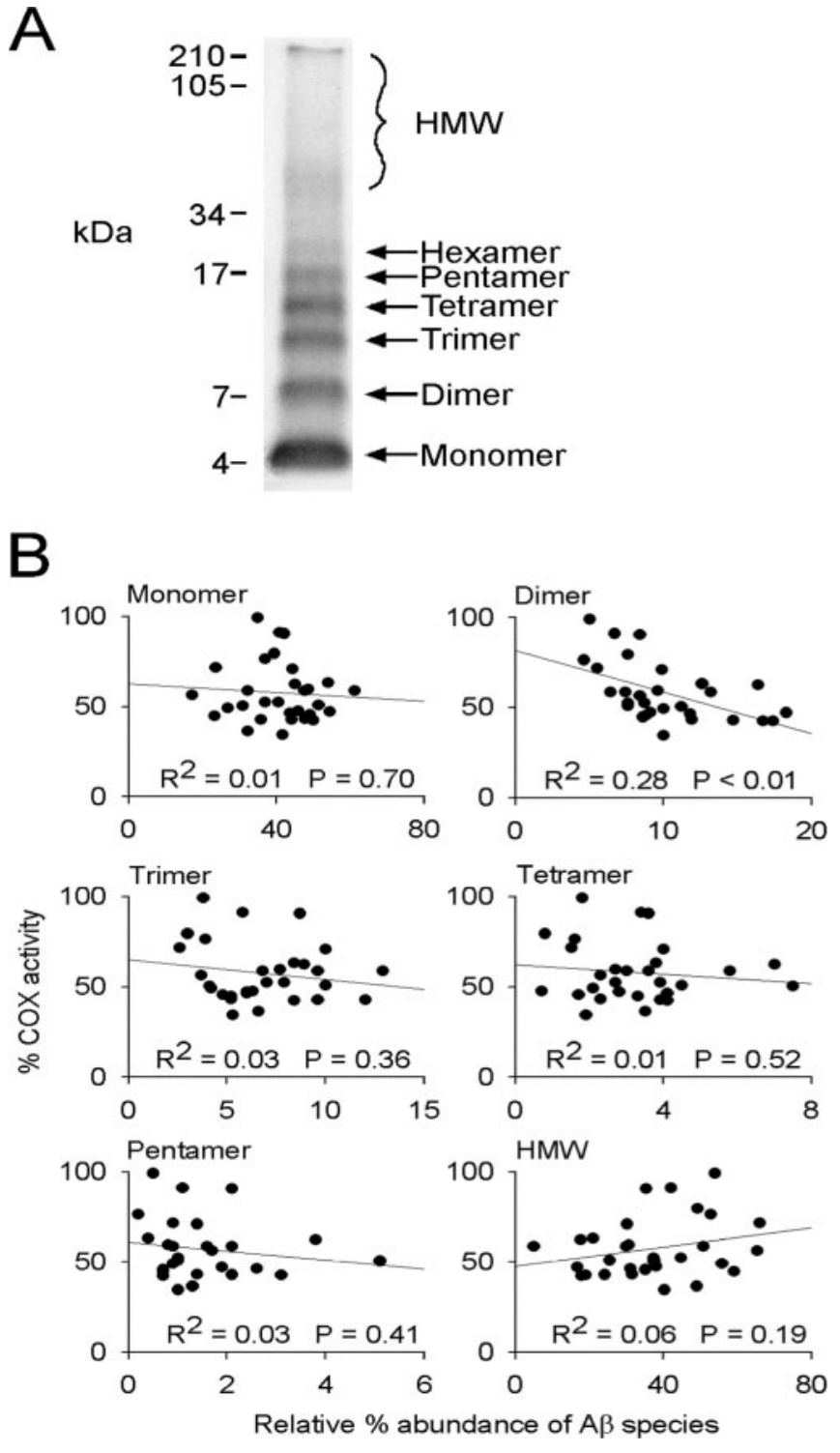

Figure 4. SDS-PAGE and Western blot analysis of $A \beta_{1-42} / \mathrm{Cu}^{2+}$ and the correlation between the abundance of $A \beta_{1-42} / \mathrm{Cu}^{2+}$ species and $A \beta$-mediated inhibition of $\mathrm{COX}$ activity. $\mathrm{A} \beta_{1-42} / \mathrm{Cu}^{2+}$ solutions were aged at $30^{\circ} \mathrm{C}$ for $0,2,4,6,10$, and $24 \mathrm{~h}$ and then either crosslinked by PICUP or assayed for their effects on COX activity in mitochondrial isolates. $A$, Different $A \beta$ species present in the cross-linked samples were resolved on $15 \%$ Tris-tricine gels, and their relative abundance, as a percentage of total $A \beta$, was determined by densitometry. $B$, The relative abundance of each $A \beta$ species was plotted against percentage $C O X$ activity in mitochondria isolates treated with the $\mathrm{A} \beta_{1-42} / \mathrm{Cu}^{2+}$ solution, and the correlation $\left(R^{2}\right)$ between the two was determined. Five $A \beta_{1-42} / \mathrm{Cu}^{2+}$ solutions were aged for the times shown and then assayed for their effects on COX activity, relative to vehicle/ $/ \mathrm{Cu}^{2+}$ solutions aged under the same conditions, or cross-linked and then analyzed by SDS-PAGE. One hundred percent COX activity indicates no $A \beta$-mediated inhibition relative to the vehicle/ $/ \mathrm{u}^{2+}$ control treatment. Significance of the $R^{2}$ values was determined by linear regression analysis.

common contaminant of mitochondria preparations). These analyses revealed both Porin and $\mathrm{HO}-1$ immunoreactivity in the total brain homogenate fraction, but only Porin immunoreactivity in the mitochondria fraction (Figs. $5 B, C$ ), suggesting that the mitochondria preparations were relatively free of endoplasmic reticulum.

\section{COX activity in Tg2576 mouse brain mitochondria}

Preliminary analysis of COX activity in purified brain mitochondria from 18-month-old Tg2576 mice showed no differences
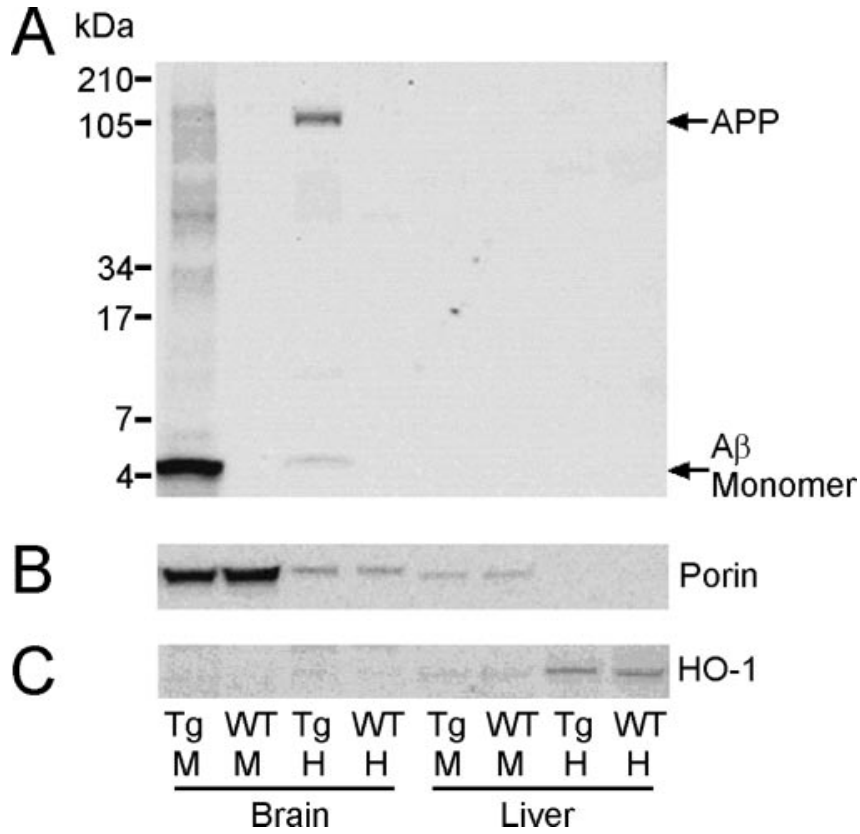

Figure 5. SDS-PAGE and Western blot analysis of APP and $A \beta$ in brain mitochondria of $\operatorname{Tg} 2576$ mice. $A, A \beta$ and APP in total homogenate $(H)$ and mitochondria $(M)$ samples from the brain and liver of 18-month-old Tg2576 (Tg) and wild-type (WT) mice were resolved on 10 $20 \%$ Tris-tricine gels and Western blotted with W02 for A $\beta / A P P$. $A \beta$ was greatly enriched in the brain mitochondria of $\operatorname{Tg} 2576$ mice but nondetectable in brain mitochondria of agematched WT controls. Fifty micrograms of total protein (for mitochondria samples) or $30 \mu \mathrm{g}$ of total protein (for homogenate samples) was loaded per lane. The gels were reprobed with Porin for mitochondria $(B)$ or H0-1 for endoplasmic reticulum $(C$, and this revealed that the mitochondria fractions were relatively free from endoplasmic reticulum.

from controls when mitochondria were prepared in isolation buffer with EGTA $\left(61.5 \pm 5.0 \mathrm{k} \cdot \mathrm{min}^{-1} \cdot \mathrm{mg}^{-1}\right.$ mitochondrial protein for Tg2576, $66.0 \pm 4.0$ for controls; $p=0.37$; ANOVA; $n=3$ mitochondria isolates) or without EGTA $(47.4 \pm 0.8$ $k \cdot \min ^{-1} \cdot \mathrm{mg}^{-1}$ mitochondrial protein for $\mathrm{Tg} 2576,44.9 \pm 2.9$ for controls; $p=0.22$; ANOVA; $n=3$ mitochondria isolates).

\section{Discussion}

We found that specific inhibition of the terminal respiratory chain enzyme COX can be obtained when mitochondria isolates are exposed to $\mathrm{A} \beta_{1-42}$, but that maximal inhibition requires specific pre-aging of the $A \beta$ preparation. Inhibition of COX activity increased with $\mathrm{A} \beta_{1-42}$ aging up to $6 \mathrm{~h}$ and then declined progressively with continued aging to $48 \mathrm{~h}$. This is consistent with a model in which monomeric $A \beta$ is relatively nontoxic, but the formation of LMW oligomers, a time-dependent process, correlates with an increase in $\mathrm{A} \beta$ toxicity. Furthermore, it is consistent with a model in which continued aging of the $A \beta$ solution leads to a decrease in the abundance of the toxic LMW oligomers and an increase in HMW oligomers, and possibly protofibrils and fibrils, all of which are relatively nontoxic. Such a model has been proposed and supported by other studies (Dahlgren et al., 2002; Walsh et al., 2002; Wang et al., 2002). To further investigate this model, we correlated the observed temporal pattern of $\mathrm{A} \beta$ mediated COX inhibition with the relative abundance of individual LMW oligomers. To do this, it was essential to first cross-link the $\mathrm{A} \beta_{1-42}$ solutions (using PICUP) because many of the $\mathrm{A} \beta_{1-42}$ LMW oligomers appeared sensitive to denaturing conditions and as such were nondetectable when using SDS-PAGE. We observed that the level of $\mathrm{A} \beta_{1-42}$-mediated COX inhibition correlated significantly with the abundance of dimeric $A \beta_{1-42}$. No other 
$\mathrm{A} \beta_{1-42}$ species detected throughout the $48 \mathrm{~h}$ aging period (monomers, LMW oligomers from trimers up to hexamers, or HMW $\mathrm{A} \beta$ ) showed any correlation with the observed COX inhibition. Our data therefore indicate that in vitro inhibition of COX is caused by the time-dependent formation of dimeric $\mathrm{A} \beta_{1-42}$.

The specific inhibition of $\mathrm{COX}$ by $\mathrm{A} \beta$, compared with other members of the mitochondrial ETC, is consistent with previously published data (Canevari et al., 1999; Parks et al., 2001; Casley et al., 2002a). These reports generally used a truncated 11 amino acid form of the $\mathrm{A} \beta\left(\mathrm{A} \beta_{25-35}\right)$ to generate their specificity data. Casley et al. (2002a) did demonstrate $A \beta_{1-42}$-mediated inhibition of purified bovine $\mathrm{COX}$ and coupled respiration in rat brain mitochondria but did not assay for its effects on other ETC enzyme complexes. Using $A \beta_{25-35}$ to demonstrate specific inhibition of COX activity may provide some important data with respect to $\mathrm{A} \beta$ domains involved in potential $\mathrm{COX}-\mathrm{A} \beta$ interactions, but $A \beta_{1-42}$ is the form of $A \beta$ increasingly implicated in the development of $\mathrm{AD}$ and as such may be more indicative of potential $\mathrm{A} \beta$-mediated mechanisms occurring in the $\mathrm{AD}$-affected brain.

The presence of free $\mathrm{Cu}^{2+}$ was essential for the observed $\mathrm{A} \beta_{1-42}$-mediated inhibition of COX activity. Removal of $\mathrm{Cu}^{2+}$, via omission or the addition of the chelator EGTA, alleviated the inhibition of COX. The role for $\mathrm{Cu}^{2+}$ in the observed COX inhibition may be several-fold. It may facilitate $A \beta$ oligomerization (Atwood et al., 1998; Klug et al., 2003), may facilitate the formation of specific $A \beta$ conformers such as dityrosine $A \beta$ (Galeazzi et al., 1999; Curtain et al., 2001; Atwood et al., 2004), or may facilitate $\mathrm{A} \beta-\mathrm{COX}$ interaction, serving as a ligand. A precedent for the latter scenario may be the adriamycin/ $/ \mathrm{Fe}^{3+}$-mediated inhibition of COX observed by Hasinoff and Davey (1988). These authors found that adriamycin inhibited COX with an inhibition constant of $12 \mu \mathrm{M}$ when in the presence of $\mathrm{Fe}^{3+}$, and this inhibition was lost when the metal was removed by chelators.

The requirement for free metal cations for $\mathrm{A} \beta_{1-42}$-mediated inhibition of COX activity appeared specific toward $\mathrm{Cu}^{2+}$, because no COX inhibition was detected when using $\mathrm{Fe}^{2+}, \mathrm{Fe}^{3+}$, or $\mathrm{Zn}^{2+}$. It is unlikely that this was caused by a limited potential for $\mathrm{A} \beta$ to interact with metals other than $\mathrm{Cu}^{2+}$, because it has been shown previously that $\mathrm{A} \beta$ binds and interacts with various metals, including $\mathrm{Fe}^{2+}, \mathrm{Fe}^{3+}$, and $\mathrm{Zn}^{2+}$ (Atwood et al., 1998). It is possible, therefore, that although $\mathrm{A} \beta$ may interact with various metals and these metals differentially affect $A \beta$ conformation (Atwood et al., 2004), its interaction with $\mathrm{Cu}^{2+}$ specifically generates the conditions required to mediate an inhibitory affect on COX activity. Further study is required to determine the nature of this specificity.

The relevance of our findings to the in vivo $\mathrm{A} \beta$-mediated neurodegeneration characteristic of $\mathrm{AD}$ is restricted to the assumptions that $\mathrm{A} \beta$ has access to mitochondria of the $\mathrm{AD}$-affected brain and that it is present within the mitochondria at concentrations high enough to exert an inhibitory affect on COX activity. With respect to the first assumption, recent reports provide some evidence that $\mathrm{A} \beta$ does occur within brain mitochondria of human $\mathrm{AD}$ patients and transgenic $\mathrm{AD}$ mice. Anandatheerthavarada et al. (2003) provided evidence that the full-length APP can insert into the outer membrane of mitochondria from cortical neurons of transgenic AD mice, whereas Lustbader et al. (2004) colocalized $\mathrm{A} \beta$ with mitochondria in human $\mathrm{AD}$-affected brains. In addition to this, the data that we present here have shown readily detectable levels of $\mathrm{A} \beta$ associated with the mitochondria fraction in brains from Tg2576 mice, without the requirement for stringent solublization procedures. These data indicate that $\mathrm{A} \beta$ may be delivered to the mitochondria after processing of the APP within other regions of the cell or that $\mathrm{A} \beta$ is produced de novo within the mitochondria, with APP processing at the mitochondrial membrane generating an intra-mitochondrial pool of $\mathrm{A} \beta$. Evidence for the latter possibility has emerged recently with Hansson et al. (2004) demonstrating the presence of active $\gamma$-secretase complexes within purified rat brain mitochondria.

Whether $\mathrm{A} \beta$ can accumulate within mitochondria of the $\mathrm{AD}$ affected brain to concentrations required to inhibit COX to the extent shown here remains to be determined. To partly address this, we measured COX activity in 18-month-old Tg2576 and WT mice. Although we observed considerably elevated levels of $A \beta$ in Tg2576 brain mitochondria, we did not find decreased COX activity as recently reported by Anandatheerthavarada et al. (2003). Another recent report using PC12 cells overexpressing Swedish mutant APP also found a moderate decrease in COX activity in transfected cells (Keil et al., 2004). The mitochondrial preparations in both of these reports appear to have excluded EGTA or EDTA, whereas we used the standard EGTA-containing isolation medium for our mouse brain mitochondrial preparations. Because $\mathrm{A} \beta$-mediated inhibition of COX appears to be reversible by the addition of EGTA (Fig. $4 B$ ), we prepared EGTA-free mitochondria isolates from 18-month-old mice. Although COX activity was decreased by the removal of EGTA, there was no difference in COX activity between WT and Tg2576 mice. Further work is clearly needed to determine whether variations in the mitochondrial isolation or COX assay conditions can affect such results. Importantly, the extent to which COX activity is decreased in Tg2576 mouse brain mitochondria, as reported by Anandatheerthavarada et al. (2003), may be determined by the region of brain from which the mitochondria are isolated.

The concentrations of $\mathrm{A} \beta$ used in this study to generate $50-$ $70 \%$ inhibition of COX activity may be considered high with respect to other $\mathrm{A} \beta$ toxicity assays, particularly cell-based toxicity assays in which low micromolar ranges of $A \beta$ are generally used to generate a significant decline in cell viability. Such assays generally use considerably longer incubation periods to observe any $\mathrm{A} \beta$-mediated effects (i.e., up to several days as opposed to $5 \mathrm{~min}$ for our $A \beta /$ mitochondria isolate incubations) and therefore are likely to be indicative of different toxicity mechanisms. Nonetheless, to partly address these concerns, our data indicate that the observed inhibition of COX activity was caused by the formation of dimeric $\mathrm{A} \beta_{1-42}$, and this species at any given time accounted for only $\sim 10 \%$ of the total $A \beta$. Thus, when the mitochondria isolates were incubated with $\mathrm{A} \beta$ at a final concentration of 167 $\mu \mathrm{M}$, it can be argued that they were exposed to only $\sim 17 \mu \mathrm{M}$ of the toxic species. If correct, dimeric $\mathrm{A} \beta_{1-42}$ shows a similar potency to cyanide, a classic inhibitor of COX. Chronic exposure of the mitochondria to relatively lower concentrations of $\mathrm{A} \beta$, a scenario probably more representative of conditions within the $\mathrm{AD}$ affected brain, may well lead to physiologically significant levels of COX inhibition. Our data clearly demonstrate the accumulation of $\mathrm{A} \beta$ within the mitochondria fraction of $\operatorname{Tg} 2576$ mouse brain, relative to the total brain homogenate. Further studies are needed to determine whether the subcellular distribution of $\mathrm{A} \beta$ rich mitochondria coincides with specific regions of a single cell, such as the synapse, that correlate with the histopathology characteristic of $\mathrm{AD}$.

The in vitro data presented here are consistent with a model in which the formation of dimeric $\mathrm{A} \beta_{1-42}$, when in the presence of free $\mathrm{Cu}^{2+}$, leads to inhibited activity of the mitochondrial ETC enzyme COX. $\mathrm{A} \beta_{1-42}$ and $\mathrm{Cu}^{2+}$ levels are elevated in regions of the AD-affected brain (Lovell et al., 1998; McLean et al., 1999; Naslund et al., 2000), and COX is decreased in the AD brain 
(Maurer et al., 2000; Cottrell et al., 2001, 2002). Our data are therefore consistent with the possibility that the formation of dimeric $\mathrm{A} \beta_{1-42}$ in the presence of $\mathrm{Cu}^{2+}$, and subsequent inhibition of COX, may be an important contributor to the neurodegeneration of $\mathrm{AD}$.

\section{References}

Anandatheerthavarada HK, Biswas G, Robin M-A, Avadhani NG (2003) Mitochondrial targeting and a novel transmembrane arrest of Alzheimer's amyloid precursor protein impairs mitochondrial function in neuronal cells. J Cell Biol 161:41-54.

Anderson MF, Sims NR (2000) Improved recovery of highly enriched mitochondrial fractions from small brain tissue samples. Brain Res Protoc 5:95-101.

Atwood CS, Moir RD, Huang X, Scarpa RC, Bacarra NME, Romano DM, Hartshorn MA, Tanzi RE, Bush AI (1998) Dramatic aggregation of Alzheimer $\mathrm{A} \beta$ by $\mathrm{Cu}(\mathrm{II})$ is induced by conditions representing physiological acidosis. J Biol Chem 273:12817-12826.

Atwood CS, Perry G, Zeng H, Kato Y, Jones WD, Ling K-Q, Huang X, Moir RD, Wang D, Sayre LM, Smith MA, Chen SG, Bush AI (2004) Copper mediates dityrosine cross-linking of Alzheimer's amyloid- $\beta$. Biochemistry 43:560-568.

Bitan G, Lomakin A, Teplow DB (2001) Amyloid $\beta$-protein oligomerization: prenucleation interactions revealed by photo-induced cross-linking of unmodified proteins. J Biol Chem 276:35176-35184.

Bitan G, Vollers SS, Teplow DB (2003a) Elucidation of primary structure elements controlling early amyloid $\beta$-protein oligomerization. J Biol Chem 278:34882-34889.

Bitan G, Kirkitadze MD, Lomakin A, Vollers SS, Benedek GB, Teplow DB (2003b) Amyloid $\beta$-protein $(A \beta)$ assembly: $A \beta 40$ and $A \beta 42$ oligomerize through distinct pathways. Proc Natl Acad Sci USA 100:330-335.

Canevari L, Clark JB, Bates TE (1999) $\beta$-Amyloid fragment 25-35 selectively decreases complex IV activity in isolated mitochondria. FEBS Lett 457:131-134.

Casley CS, Canevari L, Land JM, Clark JB, Sharpe MA (2002a) $\beta$-Amyloid inhibits integrated mitochondrial respiration and key enzyme activities. J Neurochem 80:91-100.

Casley CS, Land JM, Sharpe MA, Clark JB, Duchen MR, Canevari L (2002b) $\beta$-Amyloid fragment 25-35 causes mitochondrial dysfunction in primary cortical neurons. Neurobiol Dis 10:258-267.

Citron M, Oltersdorf T, Haass C, McConlogue L, Hung A, Seubert P, VigoPelfrey C, Lieberberg I, Selkoe DJ (1992) Mutation of the beta-amyloid precursor protein in familial Alzheimer's disease increases beta-protein production. Nature 360:672-674.

Cottrell DA, Blakely EL, Johnson MA, Ince PG, Turnbull DM (2001) Mitochondrial enzyme-deficient hippocampal neurons and choroidal cells in AD. Neurology 57:260-264.

Cottrell DA, Borthwick GM, Johnson MA, Ince PG, Turnbull DM (2002) The role of cytochrome $c$ oxidase deficient hippocampal neurones in Alzheimer's disease. Neuropathol Appl Neurobiol 28:390-396.

Curtain CC, Ali F, Volitakis I, Cherny RA, Norton RS, Beyreuther K, Barrow CJ, Masters CL, Bush AI, Barnham KJ (2001) Alzheimer's disease amyloid- $\beta$ binds copper and zinc to generate an allosterically ordered membrane-penetrating structure containing superoxide dismutase-like subunits. J Biol Chem 276:20466-20473.

Dahlgren KN, Manelli AM, Stine WBJ, Baker LK, Krafft GA, LaDu MJ (2002) Oligomeric and fibrillar species of amyloid- $\beta$ peptides differentially affect neuronal viability. J Biol Chem 277:32046-32053.

Dodart JC, Bales KR, Gannon KS, Greene SJ, DeMattos RB, Mathis C, DeLong CA, Wu S, Wu X, Holtzman DM, Paul SM (2002) Immunization reverses memory deficits without reducing brain $\mathrm{A} \beta$ burden in Alzheimer's disease model. Nat Neurosci 5:452-457.

Duara R, Grady C, Haxby J, Sundaram M, Cutler NR, Heston L, Moore A, Schlageter N, Larson S, Rapoport SI (1986) Positron emission tomography in Alzheimer's disease. Neurology 36:879-887.

Fancy DA, Kodadek T (1999) Chemistry for the analysis of protein-protein interactions: rapid and efficient cross-linking triggered by long wavelength light. Proc Natl Acad Sci USA 96:6020-6024.

Galeazzi L, Ronchi P, Franceschi C, Giunta S (1999) In vitro peroxidase oxidation induces stable dimers of beta-amyloid (1-42) through dityrosine bridge formation. Amyloid 6:7-13.
Hansson CA, Frykman S, Farmery MR, Tjernberg LO, Nilsberth C, Pursglove SE, Ito A, Winblad B, Cowburn RF, Thyberg J, Ankarcrona M (2004) Nicastrin, presenilin, APH-1, and PEN-2 form active $\gamma$-secretase complexes in mitochondria. J Biol Chem 279:51654-51660.

Hardy JA, Higgins GA (1992) Alzheimer's disease: the amyloid cascade hypothesis. Science 256:184-185.

Hartley DM, Walsh DM, Ye CP, Diehl T, Vasquez S, Vassilev PM, Teplow DB, Selkoe DJ (1999) Protofibrillar intermediates of amyloid $\beta$-protein induce acute electrophysiological changes and progressive neurotoxicity in cortical neurons. J Neurosci 19:8876-8884.

Hasinoff BB, Davey P (1988) The iron(III)-adriamycin complex inhibits cytochrome $c$ oxidase before its inactivation. Biochem J 250:827-834.

Haxby J, Grady C, Duara R, Schlageter N, Berg G, Rapoport SI (1986) Neocortical metabolic abnormalities precede non-memory cognitive deficits in early Alzheimer's type dementia. Arch Neurol 43:882-885.

Hirai K, Aliev G, Nunomura A, Fujioka H, Russell RL, Atwood CS, Johnson AB, Kress Y, Vinters HV, Tabaton M, Shimohama S, Cash AD, Siedlak SL, Harris PL, Jones PK, Petersen RB, Perry G, Smith MA (2001) Mitochondrial abnormalities in Alzheimer's disease. J Neurosci 21:3017-3023.

Hsiao K, Chapman P, Nilsen S, Eckman C, Harigaya Y, Younkin S, Yang F, Cole G (1996) Correlative memory deficits, A $\beta$ elevation, and amyloid plaques in transgenic mice. Science 274:99-102.

Huang X, Cuajungco MP, Atwood CS, Hartshorn MA, Tyndall JD, Hanson GR, Stokes KC, Leopold M, Multhaup G, Goldstein LE, Scarpa RC, Saunders AJ, Lim J, Moir RD, Glabe C, Bowden EF, Masters CL, Fairlie DP (1999) $\mathrm{Cu}(\mathrm{II})$ potentiation of Alzheimer $\mathrm{A} \beta$ neurotoxicity: correlation with cell-free hydrogen peroxide production and metal reduction. J Biol Chem 274:37111-37116.

Ida N, Hartmann T, Pantel J, Schroder J, Zerfass R, Forstl H, Sandbrink R, Masters CL, Beyreuther K (1996) Analysis of heterogeneous $\beta$ A4 peptides in human cerebrospinal fluid and blood by a newly developed sensitive Western blot assay. J Biol Chem 271:22908-22914.

Keil U, Bonert A, Marques CA, Scherping I, Weyermann J, Strosznajder JB, Muller-Spahn F, Haass C, Czech C, Pradier L, Muller WE, Eckert A (2004) Amyloid-beta induced changes in nitric oxide production and mitochondrial activity lead to apoptosis. J Biol Chem 279:50310-50320.

Klug G, Losic D, Subasinghe SS, Aguilar M-I, Martin LL, Small DH (2003) $\beta$-Amyloid protein oligomers induced by metal ions and acid $\mathrm{pH}$ are distinct from those generated by slow spontaneous ageing at neutral $\mathrm{pH}$. Eur J Biochem 270:4282-4293.

Lovell MA, Robertson JD, Teesdale WJ, Campbell JL, Markesbery WR (1998) Copper, iron and zinc in Alzheimer's disease senile plaques. J Neurol Sci 158:47-52.

Lowry OH, Rosebrough NJ, Farr AL, Randall RJ (1951) Protein measurement with the folin phenol reagent. J Biol Chem 193:265-275.

Lustbader JW, Cirilli M, Lin C, Xu HW, Takuma K, Wang N, Caspersen C, Chen X, Pollak S, Chaney M, Trinchese F, Liu S, Gunn-Moore F, Lue L-F, Walker DG, Kuppasamy P, Zewier ZL, Arancio O, Stern D, Yan SD, Wu H (2004) ABAD directly links $\mathrm{A} \beta$ to mitochondrial toxicity in Alzheimer's disease. Science 304:448-452.

Martins RN, Harper CG, Stokes GB, Masters CL (1986) Increased cerebral glucose-6-phosphate dehydrogenase activity in Alzheimer's disease may reflect oxidative stress. J Neurochem 46:1042-1045.

Maurer I, Zierz S, Moller HJ (2000) A selective defect of cytochrome $c$ oxidase is present in brain of Alzheimer disease patients. Neurobiol Aging 21:455-462.

Maynard CJ, Cappai R, Volitakis I, Cherny RA, White AR, Beyreuther K, Masters CL, Bush AI, Li QX (2002) Overexpression of Alzheimer's disease amyloid- $\beta$ opposes the age-dependent elevations of brain copper and iron. J Biol Chem 277:44670-44676.

McLean CA, Cherny RA, Fraser FW, Fuller SJ, Smith MJ, Beyreuther K, Bush AI, Masters CL (1999) Soluble pool of A $\beta$ amyloid as a determinant of severity of neurodegeneration in Alzheimer's disease. Ann Neurol $46: 860-866$.

Naslund J, Haroutunian V, Mohs R, Davis KL, Davies P, Greenard P, Buxbaum JD (2000) Correlation between elevated levels of amyloid $\beta$-peptide in the brain and cognitive decline. JAMA 283:1571-1577.

Parks JK, Smith TS, Trimmer PA, Bennett JPJ, Parker WDJ (2001) Neurotoxic $\mathrm{A} \beta$ peptides increase oxidative stress in vivo through NMDAreceptor and nitric-oxide-synthase mechanisms, and inhibit complex IV 
activity and induce a mitochondrial permeability transition in vitro. J Neurochem 76:1050-1056.

Peterson JL (1977) A simplification of the protein assay method of Lowry et al. which is more generally applicable. Anal Biochem 83:346-356.

Pike CJ, Walencewicz AJ, Glabe CG, Cotman CW (1991) Aggregationrelated toxicity of synthetic beta-amyloid protein in hippocampal cultures. Euro J Pharmacol 207:367-368.

Selkoe DJ (2001) Alzheimer's disease: genes, proteins, and therapy. Physiol Rev 81:741-766.

Trounce IA, Kim YL, Jun AS, Wallace DC (1996) Assessment of mitochondrial oxidative phosphorylation in patient muscle biopsies, lymphoblasts, and transmitochondrial cell lines. Methods Enzymol 264:484-509.
Wallace DC, Yang J, Ye J, Lott MT, Oliver NA, McCarthy J (1986) Computer prediction of peptide maps: assignment of polypeptides to human and mouse mitochondrial DNA genes by analysis of two-dimensionalproteolytic digest gels. Am J Hum Genet 38:461-481.

Walsh DM, Klyubin I, Fadeeva JV, Cullen WK, Anwyl R, Wolfe MS, Rowan MJ, Selkoe DJ (2002) Naturally secreted oligomers of amyloid $\beta$ protein potently inhibit hippocampal long-term potentiation in vivo. Nature 416:535-539.

Wang H-W, Pasternak JF, Kuo H, Ristic H, Lambert MP, Chromy B, Viola KL, Klein WL, Stine WB, Krafft GA, Trommer BL (2002) Soluble oligomers of $\beta$ amyloid (1-42) inhibit long-term potentiation but not longterm depression in rat dentate gyrus. Brain Res 924:133-140. 